\title{
THE PRESIDENCY AND THE CONSTITUTION: A LOOK AHEAD
}

\author{
Joseph E. KaLLENBACH*
}

Current fashion in scholarly discussions of the presidency is to focus upon its internal organizational arrangements and operational methods, the "style" and the "public image" of the occupant of the moment. This emphasis is by no means misplaced. The dimensions of the presidency are determined in large measure by the occupant's capacity and skill in converting his post into a center for policyinitiation and leadership in the political process. Without question, it has become a highly personalized office. Yet it is well to remind ourselves from time to time that with reference to this great office, the Constitution still "does matter."1 Underlying all that it has come to be is the constitutional framework which gives it form and substance.

\section{I}

\section{The Constitutional Foundation}

In formulating the constitutional phraseology creating this office the framers of the Constitution wrote on a clean slate. They were in the rather enviable position of being able to give concrete form to what was in their collective judgment a "model" plan of executive organization. Blending theory with practical wisdom derived from the British model and from American experience with various types of "republican" executive organization, they set down as their contribution on this subject the language of article II of the Constitution.

Viewing these original constitutional provisions in the perspective afforded by time, one is impressed first of all by the extraordinary viability and durability of the terminology hit upon in defining the President's powers, functions, and relations with the other elements making up the governmental scheme. It remains to this date without alteration. One notes further, however, that the formal amending procedure has been resorted to with unusual frequency to tinker with certain structural features of the original plan-chiefly those concerned with the mode of selection.

Since I79r, when the perfecting Bill of Rights amendments were incorporated into the Constitution, there have been fifteen amendments engrafted upon the handiwork of the framers. No less than five of these-the twelfth (I804), twentieth (I933), twenty-second (I95I), twenty-third (I96I), and the twenty-fifth (I967)have dealt with what may very properly be described as structural aspects of the

* Professor of Political Science, University of Michigan.

${ }^{1}$ Cf. Fairlie, Thoughts on the Presidency, The Public INTrerest, Autumn, 1967, at 48. 
office of President. To these might well be added three others-the fifteenth (1870), nineteenth (I920), and twenty-fourth ( 1963 ) amendments. These revisions of the original document, to be sure, were directed generally toward broadening the popular electoral base upon which government in the United States rests. But these amendments were adopted after developments through state legislation and party usage had already occurred that had converted the original plan of presidential selection into a system of indirect popular choice. These franchise-extending amendments therefore contributed very materially toward democratizing in greater measure the office of President.

Formal amendments adopted to date have been essentially responses to change in conception of the functions assigned to this office. As has been noted, the original phraseology detailing its formal powers and defining its relationships to the other organs of government remains unchanged. But it is precisely because new conceptions of the President's role in the governmental process have become institutionalized that it has been deemed necessary to introduce structural modifications by resort to the amendment procedure.

Constitutional revisions effected to date have been, essentially, accommodations dictated by the President's having assumed a more open, active leadership role in government affairs. This has resulted from the new interpretations read into his original grants of constitutional authority. Supplemented further by congressional enactments, these grants have become a vast reservoir of power and influence. The President's "headship" of the government has become far more than symbolic. The primacy of the presidency, if not of the President, as an element in the governing process, has become apparent to all. Simultaneously developments have occurred that have placed in his hands also a national party leadership role, supplementing his official governmental "headship" powers at almost every point.

\section{II}

\section{The Roles of the President}

Implicit in these developments there is discernible a certain ambivalence, even a contradiction, of purpose and result. This ambivalence arises from a duality in the roles that have come to be associated with this office. On the one hand, providing a direct popular base on which the office rests, coupled with a broadened conception of his official powers and authority, has given the President a new source of support for vigorous assertion and use of his constitutional powers vis-à-vis Congress, the courts, and the states. He speaks and acts as the people's agent. He lays claim to a mandate from them for his acts. Authority descends upon him from the nation, not from the other organs of government. Vox populi legati suprema lex est becomes his credo.

Thus when Franklin D. Roosevelt addressed Congress in 1942 in his role as President, requesting that it pass a more effective price and wage control bill, he 
underscored his request with a threat to act on his own authority if Congress failed to respond promptly. He concluded his remarkable statement with these significant words:

When the war is won, the powers under which I act (will) automatically revert to the people-to whom they belong. ${ }^{2}$

Essentially what FDR was enunciating was a kind of fuhrership principle of executive authority. As National Leader and Head of Government he was laying claim to a right to act in the name of the people for the public good, independent of congressional sanctioning of his action. Granted, he may well have been bluffing, knowing that the Congress would respond to his request, given the state of public opinion at the time; $;^{3}$ but this statement is a clear illustration of the ultimate reach of executive prerogative in an "emergency."

Added to this latitudinarian conception of the powers of the office is the idea that the President should exercise a "moral leadership" role in the affairs of the American people generally. Again in was FDR, echoing views earlier expressed by Theodore Roosevelt and Woodrow Wilson, who can be cited as voicing most emphatically this view. Shortly before his assumption of office, he characterized it as "pre-eminently a place of moral leadership." This responsibility, he went on to say, far outweighs the purely administrative functions of the offce. The range of this responsibility extends to every matter of vital concern to the people and their welfare. The presidency thus becomes an office of spiritual as well as political leadership. It combines the functions of a Caesar and a Pope. ${ }^{5}$

But when the "people" invest the President with his powers of office, they do so through a partisan electoral contest. He speaks through and for the political party whose acknowledged champion and spokesman he has become by virtue of his emerging as its nominee. Of course, his objective as a leader of a partisan faction is only to prevail over a Loyal Opposition party (or parties) with regard to certain policies he believes the government should pursue. His objective is not to utterly destroy them. ${ }^{6}$ His mandate as party leader is limited by the democratic dogma of toleration for opposing views-a concept that supplies the key to successful operation of democratic systems of government generally. In view of the non-ideological, quite decentralized character of the two major parties in the United States, moreover, this partisanship of toleration extends in great degree into the area of intra-party politics as well. Over neither his "congressional party" wing

\footnotetext{
38 Cong. REc. 7044, 77th Cong., 2d Sess. (1942) (emphasis added).

${ }^{3}$ Cf. Roche, Executive Power and Domestic Emergency: The Quest for Prerogative, 5 W. PoL. Q. $6 \mathrm{ro}$ (I952).

"Warn, Roosevelt's Approach to the Great Task, N.Y. Times, Nov. 13, I932, $\$ 8$, at I, col. I.

"Fairlie, stupra note $I$, has coined the term "Caesaropapism" to express this concept.

'The development of a sophisticated partisan politics of toleration and accommodation in the United States, with the President playing a leading role therein, is explored in illuminating fashion in R. Hofstadter, The Idea of a Party System: The Rise of a Legitmate Opposition in the United STATES, I780-r840 (I969).
} 
nor the state and local party cadres upon whose shoulders he has ridden into power can the President realistically expect to exercise a discipline and control that unites them into a solid phalanx under his leadership.

Joining in his hands these two kinds of leadership roles places the President in a somewhat awkward position. He becomes at once the surrogate of a united people and at the same time, the leader and spokesman of a faction of the people. In his first capacity he wields broad "moral leadership" and none-too-closely defined official powers as Head of State. In his latter capacity, by contrast, he speaks and acts for a segment of the people aligned in opposition to other important elements in American political society. As such, he must expect to encounter, and be obliged to tolerate, a great amount of sniping, criticism, and mulish obstructionism, if not downright sabotage, of his undertakings. Those in and out of government who speak and act for an organized, constantly evolving partisan opposition will see to that. Intent upon scoring points that will enhance their chances of taking over control of this power center at the next election, his partisan opponents are naturally loath to act in ways that might make the President and the partisan element he represents "look good" in the eyes of the national electorate; for his partisan opposition is committed to an attempt to oust him and his party when the contest for preferment is staged anew.

Because of this duality of roles, the presidency necessarily presents to the nation and the world a kind of schizophrenic aspect. As influences and pressure play upon the President from the two poles of his sometimes inconsistent roles, he performs his functions in a state of continual tension. Let him address the Congress-and his national constituency as well-in discharge of his constitutional responsibility to "give to the Congress information on the state of the Union, and recommend to their consideration such measures as he shall deem necessary and expedient," and the cry arises immediately for "equal time" on the communications media for his Loyal Opposition to reply. His engagement in active congressional campaigning to further election of partisan colleagues pledged to support of his policies immediately sparks charges of "slicksterism" and misuse of the prestige of his office for partisan ends. Searching and sometimes embarrassing questions are raised on exactly how and by whom the expenses entailed by his campaign tours and speeches are being met. On the other hand, his failure to include an active, effective party leadership role in his conception of his official responsibilities exposes him to criticism from other directions for ineptness and unwillingness to exploit to the fullest extent the potential of his office for advancing the public welfare.

The "moral leadership" aspect of the President's modern role in governmental affairs serves further to magnify the tensions arising from his having assumed a party leadership function in addition to a greatly broadened conception of an official authority derived from the constitutional sources. One commentator recently began a short discussion of this problem in its current context in this fashion: 
Around the White House they worry quite sincerely that a lot of Americans are confusing the President with God. Their concern, of course, stems from the fear that if the populace approaches the Oval Office with spiritual expectations and then finds only a human in there, the result will be general despair and a tendency to blame everything from riots and race hatred to dope and divorce on Richard Nixon. ${ }^{7}$

In the eyes of the populace-with some assistance from Presidents themselves as well as from none-too-discerning learned commentators-the President is elevated to the status of the Great Wizard, the Healer of All the Nation's Woes. Let him fail to express his views and concern about one of the great problems of the day, and he is assailed for failure to exert appropriate "moral leadership." All would be well, it is said, if he would only sound the tocsin to battle against this or that evil in American life. It is his function to inspire the people and point the way to realization of every man's conception of the American Dream. Yet if he announces a position and issues a call for action on some burning social or economic issue-with the inevitable result of offending some elements in society who do not agree with his point of view-his critics will be quick to charge him with "creating divisiveness," "alienating" important elements of society, or "polarizing" the American Public.

\section{III}

\section{The Prospects for Change}

It is within the context of these built-in conflicts between the roles the modern presidency has assumed that one must approach the question of the possibility and desirability of change in the Constitution as it relates to this office. Given the history of failure of past efforts, both from within Congress and from outside it, to effect fundamental changes of this kind (except as to the mode of filling the office and keeping it filled), the prospects appear to be practically nil. The method by which the popular choice of the nation is determined in the selection of the President and Vice President will probably soon be brought into closer focus with political realities by formal amendment of the Constitution. Beyond that, however, the prospects for change appear slim indeed. Change in a fundamental sense is likely to occur only if some great catastrophe in the nation's life-such as, God forbid! an all-out nuclear war, or an internal upheaval of the sort apparently sought by some of our young revolutionary nihilists-should befall us.

It should never be forgotten that the modern Presidency is the product of a continual struggle for power and influence deliberately invited by the nature of the original constitutional plan. So far as concerns the constitutional ground rules setting up the arena and allocating weapons of political warfare as among the three branches of the national government, they have to date resisted all efforts to alter

\footnotetext{
"Sidey, The Presidency: Demand for "Moral Leadership," LifE, Oct. 23, I970, at 2.
} 
them by the formal amendment route. There is no good reason to believe they will not continue to do so.

Note, for example, the controversies that have arisen over the question of alteration of the original veto arrangements in the Constitution. An unusually vigorous use of this authority by Andrew Jackson produced in reaction a series of serious but unsuccessful attempts by the Whigs to cut back the veto power by constitutional amendment during the I840's. Enactment by a run-away Congress of 15 of $2 \mathrm{I}$ measures vetoed by President Andrew Johnson in the I860's ultimately demonstrated that the veto was not an absolute weapon in the hands of the President. It could be blunted by a determined congressional majority.

Later the pendulum swung the other way again. Every President from Grant to Eisenhower has expressed dissatisfaction with the original veto arrangements and pleaded for a constitutional amendment granting them the item veto over appropriation bills. Numerous pundits have endorsed the idea as a sound one. When no favorable response came from Congress, the Presidents eventually turned increasingly to the device of "impoundment" of appropriated funds which in their judgment were improvidently authorized by Congress. ${ }^{8}$ Still more recently, enactment by Congress of a major appropriation bill over President Nixon's veto has demonstrated anew that the "pull and haul" system set up by the framers as between Congress and the President in the enactment of money bills is by no means outmoded. It still works both ways.

All this is not to say, of course, that changes in the constitutionally ordained equilibrium of power as between the President, the Congress, and the courts, and as between him and state authorities has not occurred, or will not continue to occur. The role of the President in the constitutional scheme will doubtless be altered as the future unfolds; but alteration will come about through the more subtle, informal methods of constitutional change rather than by constitutional amendment. Changes in the balance of powers between Congress and the Executive that will be effected cannot be expected to eliminate the state of tension that exists between them. They may well cause it to become even more acute from time to time as the President appears in his various roles before the Congress and the American public.

For the moment it would appear that the mood in Congress and in the nation is one of seeking and exploiting new, and refurbishing old, ways of redressing the balance more explicitly on the side of congressional power and influence. This would appear to have been a more or less inevitable result, given the fact that in four of the last eight Congresses (five out of nine if the new gand Congress chosen

\footnotetext{
${ }^{8}$ For a discussion of this development, see Goostree, The Power of the President to Impound Appropriated Funds: With Special Reference to Grants-in-Aid to Segregated Activities, and Kranz, $A$ Twentieth Century Emancipation Proclamation: Presidential Power Permits Withholding of Federal Funds from Segregated Institutions, in THE PREsidencx 727 (A. Wildavsky ed. 1969); Church, Impottndment of Appropriated Funds; The Decline of Congressional Control Over Executive Discretion, 22 STAN. L. REv. 1240 (I970).
} 
in November, I970 is included) both Houses have been under the control of the President's political opposition.

It can be predicted that among the strategies Congress may be expected to pursue in the future in its never-ending tug-of-war with the President will be the following:

I. Further efforts to exploit more effectively its inquisitorial and other types of authority to command production of information relevant to public policy in the hands of the President or his agents.

2. More frequent use of a built-in concurrent resolution "cut-off" device, whereby grants of authority to the President by legislative act may be cancelled without running the risk of a veto.?

3. Wider employment of the committee-clearance-in-advance procedure for supervising administration of particular statutes. ${ }^{10}$

4. Increased resort to House and/or Senate resolutions declarative of attitudes, intent, and understandings of the respective bodies on questions of public policy, as illustrated by the Senate's passage of the National Commitments Resolution in rg6g. ${ }^{11}$

5. Freer use by the Senate of its power to reject nominations to major posts by the President. Illustrative of the point was the Senate's breaking a precedent of some forty years standing by refusing to confirm two presidential nominations to the Supreme Court within the past two years. This followed soon after a resignation of an incumbent Justice was induced by a Senate inquiry into his qualifications while he was being considered as the President's nominee for the post of Chief Justice.

6. Fuller exploitation by Congress of its "power of the purse" to limit presidential discretion in various policy-initiating and policy-executing areas. The ultimate reach of this potent weapon remains unexplored, at least in the minds of some members of Congress. As indicated in the Senate debates on the Cooper-Church Amendment to the Military Procurement Act of 1970 , it might conceivably be used in such a way

\footnotetext{
${ }^{\circ}$ Cf. Buchwalter, The Congressional Concurrent Resolution: A Search for Foreign Policy Influence, r4 Midwest J. Pol. Scr. 434 (I970).

${ }^{10} \mathrm{Cf}$. J. Harris, Congressional, Control of Administration $237 \mathrm{et} \mathrm{seq.} \mathrm{(I965).} \mathrm{As} \mathrm{a} \mathrm{result} \mathrm{of} \mathrm{re-}$ peated clashes between President L.B. Johnson and Congress on inclusion of various types of "committee veto" provisions in statutes, a subcommittee of the Senate Judiciary Committee chaired by Senator Ervin, of North Carolina, conducted extensive hearings on this problem in 1967. See Hearings on the Separation of Powers Before the Subcomm. on Separation of Powers of the Senate Comm. on the Judiciary, goth Cong., Ist Sess. (I967).

${ }_{11}$ S. REs. 85, 9Ist Cong., Ist Sess. (I969). The resolution, which was passed by a 70-I6 vote, reads as follows:

Resolved, That (I) a national commitment for the purpose of this resolution means the use of armed forces of the United States on Foreign territory, or a promise to assist a foreign country, government, or people by the use of armed forces or financial resources of the United States, either immediately or upon the happening of certain events, and (2) it is the sense of the Senate that a national commitment by the United States results only from affirmative action taken by the executive and legislative branches of the United States by means of a treaty, statute, or concurrent resolution of both Houses of Congress specifically providing for such commitment.
} 
as to substitute Congressional judgment for that of the President in the exercise of his commander-in-chief functions with respect to matters of military strategy and tactics in an area of actual combat. It might be observed, in passing, that when Congress in I942 sought to use the "power of the purse" to usurp the President's constitutionally based power of removal over subordinate executive officials, it was rebuked by the Supreme Court. ${ }^{12}$ But the Court's ruling in that instance turned on a point of constitutional construction that carefully evaded the basic question of implied limits on the power of the purse growing out of the Constitution's allocation of executive powers to the President.

The long-range impact of these and other devices Congress may be expected to experiment with in the next decade on the constitutional balance of power between the two branches cannot be fully appraised at this point. They may well prove to be futile and ineffective. The pressures that exist both in the foreign and domestic policy-making areas appear to make aggrandizement of the executive side of government an imperative. Efforts in Congress to retrieve for itself a wider decision-making authority may simply prove to be impractical.

\section{IV}

\section{Constitutional Amendments}

Meanwhile, the impact of both recent and anticipated constitutional revisions pertaining to the office of President can be evaluated. These changes by amendment, it has been pointed out above, have reference to the mode of election and perfecting the arrangements for succession, rather than to the powers of the office per se. Nevertheless they have a significance with respect to the extra-constitutional role of the President as party leader in ways that have not been widely appreciated.

The twenty-second amendment, which became a part of the constitutional plan in I95I, has usually been conceived of as an instrument for enforcing a rule of rotation with respect to the holding of the official powers of the office. And so it is. But it may be suggested that the amendment was understood by its more perceptive advocates as significant primarily as an instrument for regulating party government. Its immediate impact was to enforce a rule of limited tenure on a national party head by arbitrarily displacing him after an interval as the dominant force in his party nationally.

After all, as had been demonstrated by the Taft and Hoover candidacies in 1912 and I932, respectively, an incumbent President seeking re-election could be turned out of office after one term if the people were so inclined. But no incumbent President since I 900 who had sought renomination by his party had been rejected as its nominee. It was the domination of the national party convention by an incumbent President so as to compel his own renomination that was the primary target of the amendment. Rather than tinker with the constitutional arrangements relating to the official

\footnotetext{
${ }^{12}$ United States v. Lovett, 328 U.S. 303 (1946).
} 
powers and duties of his office (on the terms of which probably no agreement could have been achieved in Congress), this indirect bi-partisan approach to the end desired -a freeing of the party from one-man rule-was adopted.

Again, one may discern a connection between the twentieth amendment and the twenty-fifth amendment in their bearing on the question of succession in the party leadership aspect of the presidency. The main object of the twentieth amendment, of course, was to effect a closer coordination between the beginning of an in-coming President's term of office and the functioning of the newly-chosen Congress under his leadership. An infrequently noted provision of the amendment, however, was the language of its third section. This section makes clear that in the contingency of an inconclusive presidential election and an ensuing deadlock in the House of Representatives, the new Vice President-elect must temporarily assume the post of Acting President until the deadlock is resolved. His doing so, it is made clear, does not permanently displace the President-to-be.

This language went part way, at least, toward resolving the question whether a Vice President might legitimately act as President without becoming President-an unresolved issue that had been a serious barrier to implementation of the original constitutional arrangements regarding succession in the event of the President's disability. Beyond that, however, it implied that the President and the Vice President, rather than being regarded as candidates for two separate offices, should be looked upon as a "team." The Vice President, as the potential deputy party leader, should therefore be politically compatible with and enjoy the confidence of the President in that capacity.

In addition to legitimizing either a temporary or permanent Head of State role for the Vice-President-an important criterion for any arrangement relative to the presidential succession ${ }^{13}$-this provision led almost immediately to introduction of the usage of the national party convention's deferring to the presidential nominee's wishes in the selection of a vice presidential running mate. In other words, the national party leader was accorded the privilege of naming the deputy leader. This practice manifested itself in the Democratic Party's convention in I940 when F.D.R. imposed upon a rather reluctant body of delegates his choice of running mate. The precedent of consulting the presidential nominee and deferring to his wishes in the matter of the vice presidential nomination has been followed in every national major party convention, with one exception, since then. ${ }^{14}$

This usage, in its turn, led directly to inclusion of the language of section 2 in the twenty-fifth amendment. That section, which follows immediately upon language

\footnotetext{
${ }^{13}$ Cf. Wildavsky, Presidential Succession and Disability: Policy Analysis for Unique Cases, in THE PRESIDENCY 777 (A. Wildavsky ed. I969).

${ }^{14}$ Adlai Stevenson, the Democratic Party's nominee in 1956, permitted the party convention to exercise a free choice in the matter of the vice presidential nomination. His endorsement of Senator Sparkman, of Alabama, as his running mate in the $\mathbf{I 9 5 2}$ election had given rise to considerable criticism in certain "liberal" circles of the party, who maintained that it had weakened the ticket.
} 
in the amendment declaring that the Vice President shall "become" President in case of the removal of the President, or his death or resignation, reads as follows:

Whenever there is a vacancy in the office of the Vice President, the President shall nominate a Vice President who shall take office upon confirmation by a majority vote of both Houses of Congress.

Potentially this provision of the amendment is of far greater significance than the other sections concerning succession to the powers and duties of the office of President by the Vice President in the event of the President's disability. It has as its objective keeping the line of succession filled by a President-in-waiting, thus obviating the necessity, for all practical purposes, of going beyond the vice presidency in providing a successor. In view of the increasing importance that has come to attach to the vice presidential post so far as the party leadership aspect of the office of President is concerned, it is remarkable that this provision in the amendment received comparatively little attention in the Congressional debates. It deserved far more attention than it was given. Of all the provisions in the amendment, it is the one that may well prove to be either unworkable in practice or, if it works, of profound significance in its impact upon the office of President in its party leadership aspect.

Since World War II, the vice presidency has become the most frequently used stepping stone to the presidency, or at least to preferment as the nominee for that post by the President's party. Two presidentially designated deputy party leaders, Harry S. Truman and L. B. Johnson, have succeeded to the office of President upon the death of incumbents and have gone on to win election in their own right for full terms. Two other incumbent Vice Presidents, Richard Nixon in 1960 and Hubert Humphrey in rg68, were nominated with the blessing of the incumbent President of their respective parties, but were defeated in their runs for the big prize. Nixon, of course, was successful in a second try after an intervening election. Increasing reliance of Presidents from F.D.R. to Nixon on their Vice Presidents to carry a major share of the party campaigning burden in off-year congressional elections demonstrates the point that the Vice President's $e x$ officio role as deputy party leader is something more than an empty title.

It is this dimension of the President's position in relation to his party that raises doubts about the feasibility of this provision of the amendment. Placing the responsibility in his hands to nominate a person to fill a vice presidential vacancy, insofar as that offcer becomes an ex officio deputy party leader, is of course, in line with the practice that has come to prevail at the national party convention in selecting the vice presidential nominee. Presumably a President will consult other party leaders in and out of Congress in settling on his choice, in case the post becomes vacant, as he does at a national party convention. But his filling a vacancy in the office is not merely that of selecting a candidate for election, subject to the suffrage 
of the people. It is to fill an office with prescribed constitutional and statutory powers and duties plus other important partisan political functions.

The twenty-fifth amendment proposes to give legitimacy to a new incumbent in the vice presidency as an officer by requiring that his appointment be confirmed by a majority vote in both Houses of Congress. This is likely to be forthcoming if the President's party has a majority in both Houses. But what if the President's party does not have majority control in Congress?

This is no idle speculation. In no less than six of the last thirteen Congresses, the President's party has been in the minority in both Houses of Congress. May it be readily assumed in this kind of situation that as a matter of partisan "courtesy" the majority party in the two Houses will readily go along with the President's selection of a person who will become his "heir apparent" as party leader? Would the temptation not be too strong for the President's loyal opposition to simply "sit" on the nomination, keep the vice presidency vacant, and thereby, under arrangements regarding the presidential succession presently set forth in the Presidential Succession Act of I947, retain the opposition party's House Speaker in the position of being only "one heartbeat away" from the presidency itself? 15

Other features of the twenty-fifth amendment are less open to criticism on the ground that they fail to take into account the fact that the presidency has become a party leadership post as well as a powerful Headship of State office. The arrangements of section 3 of the amendment providing for temporary assumption of the powers and duties of the office of President by the Vice President upon due notice and request by a temporarily disabled President are in line with understandings reached on an informal basis by President Eisenhower and his Vice President, as well as by Presidents Kennedy and Johnson and their "Deputy Presidents." These "understandings," it should be noted, had followed upon resolution of the point in the twentieth amendment that a Vice President might "act" as President without "becoming" President.

The rather complex procedure provided for effecting a temporary succession by a Vice President when the President is unable to declare his disability commendably takes into account the partisan political aspects of the succession problem as well as the official duty aspects. On the partisan side, associating the heads of the principal departments (or of "such other body as Congress may by law provide") with the

\footnotetext{
${ }^{15}$ Senator Birch Bayh's One Heartbeat Away (I958) is an illuminating, detailed account of the struggle in Congress to get the Presidential Disability Amendment drafted and passed. Senator Bayh played a leading role in this effort on the Senate side. The suggestion to incorporate a provision in the amendment to cover the matter of filling a vice presidential vacancy in the manner eventually adopted came from a number of sources. See Id. at 32. In earlier drafting endeavors it was planned to incorporate provisions abolishing the provisions in the Presidential Succession Act of r947 which placed the House Speaker and President pro tem of the Senate in the line of succession; but for reasons of legislative strategy this feature was omitted from the amendment. Had this provision been included and the Secretary of State been named as the next officer in the succession line beyond the Vice President, the provision for filling the vice presidency incorporated in the amendment would be much less vulnerable to criticism.
} 
decision of the Vice President to assume the powers of the presidency in this kind of contingency affords protection against a rash challenge of the party head by an ambitious Vice President, or perchance, may spur him to take necessary action.

A similar procedure must be invoked by a Vice President to resist a President he deems still disabled who seeks to resume the powers of office. But the support of a two-thirds majority in both branches of Congress must be secured by a Vice President within a specified time limit if he is to be permitted to retain the official powers of the presidency in the face of a claim by the incumbent President that his disability has been eliminated.

In simpler terms, the amendment provides a rational procedure by which a President regarded as unable to exercise his official powers as head of state, and his unofficial functions as party chief as well, may be suspended though not permanently removed. The procedure adopted seeks to provide a check upon the Vice President's action in such a case both as to its impact on the party leadership role as well as upon the head of state role of the President. A contingency of the sort that might involve Congress as the ultimate judge of the merits of the claims of rival contenders for the office is very unlikely to occur; but if it does, requiring a substantial bipartisan majority in each House of Congress to suspend the regularly elected President from office is appropriate insurance that this step will be taken only in the event a crisis of major proportions has arisen - one transcending ordinary considerations of partisan advantage.

A final point of consideration concerns the impact of what will probably become the twenty-sixth amendment on the dual roles of head of state and party head the President has come to occupy. The likelihood appears strong that a constitutional amendment will soon be adopted abolishing the electoral college procedure for registering the will of voters of the nation in the selection of the President and Vice President, and making a direct vote of the people from the nation at large determinative of the outcome. But a nagging problem has appeared with regard to such an amendment. What procedure should be provided to deal with the contingency of there not being a conclusive enough plurality in the popular voting for any pair of candidates for these offices to be deemed elected?

In the version of the direct election amendment proposal passed by the House in September, 1969 , by approximately a five-to-one majority, this contingency is dealt with by a provision that if no ticket receives a plurality of forty per cent or more of the total vote, a run-off popular election will be held within a matter of weeks between the two leading pairs of candidates. In Senate debate on the amendment proposal during the months of September and October of I970, opponents of the direct election plan centered their fire heavily on these provisions of the Housepassed plan. Alternatives advanced by opponents to the direct election system looked toward preserving the present electoral vote system, with possibly an "automatic" electoral vote based on the present electoral vote distribution formula. These alterna- 
tive plans also embraced the idea of resolving an inconclusive electoral vote result by referring the presidential and vice presidential contests, as now provided, to the House and Senate respectively; or possibly by reference of these contests to a joint session of the two Houses, with each Senator or Representative casting an individual vote in each contest.

Whatever the new elective system adopted may prove to be, if the present method of resolving an inconclusive first step result is retained or a system of joint voting by the two Houses is substituted as the method for achieving a final result in this contingency, extremely serious repercussions may well be felt. The "near miss" scored by Governor Wallace in his proclaimed intention to capture enough electoral votes to produce an inconclusive electoral vote result in the Ig68 election, following upon the four-party contest in 1948 and the "unpledged elector" ploy used by dissident States Rights Democrats in I960, has brought home the point to many of the leading members of the two major parties that to continue to rely on the present electoral vote method may well lead to disaster so far as the two-party system is concerned. A presidential election resolved by the "bartering" of a bloc of third or fourth party electoral votes, or by political horse-trading in the House and/or Senate, would shake the structure of the two major parties to their foundations.

While this thought has proved to be the catalyst that has finally produced some movement in Congress to substitute a more realistic, politically logical mode of electing the President for the electoral college system, there has been inadequate attention given to the question in Congress of what would be in store for its members if ever they should be called upon to resolve an inconclusive first stage in the election of the President. A realistic appraisal of the situation confronting them should be made.

In the I 688 election, if less than one-half of one per cent of the major party vote in Ohio and Missouri had shifted from Nixon to Humphrey, the electoral votes of those states, totaling 38 , would have gone to the latter rather than the former. An electoral vote deadlock would have resulted, with no pair of candidates for President and Vice President receiving a majority. Assume further that neither of the major party candidates, in line with their pledges during the course of the campaign, would have struck a political bargain with Wallace for enough of his electoral votes to surmount the majority vote hurdle. If the election had been referred to the House, the following situation would have resulted in the 9 Ist Congress: ${ }^{16}$

Thus eleven House delegations in states carried by Nixon would have been under a heavy political "cross-pressure." That is to say, the Democrats who were in the majority in each of those states would have been confronted by the difficult choice of sticking with their party's candidate and giving their states' votes in the House voting to the rejected popular choice therein, or going along with the will of a

\footnotetext{
${ }^{10}$ The electoral results used in deriving this and the following tables are those found in the
} Congressional Quarterzy I968 Elections Supplement (I969). 
TABLE I

Distribution of House Unit Votes for President, ig68

\begin{tabular}{lrcccc}
\hline \hline $\begin{array}{l}\text { States carried } \\
\text { in popular vote: }\end{array}$ & Total & $\begin{array}{c}\text { House del- } \\
\text { egation Rep. }\end{array}$ & $\begin{array}{c}\text { House del- } \\
\text { egation Dem. }\end{array}$ & $\begin{array}{c}\text { House del- } \\
\text { egation AlP }\end{array}$ & $\begin{array}{c}\text { Evenly } \\
\text { divided }\end{array}$ \\
\hline By Nixon & 32 & I7 & II & 0 & 4 \\
By Humphrey & I3 & 2 & Io & 0 & I \\
By Wallace & 5 & 0 & 5 & 0 & 0 \\
\cline { 2 - 6 } Totals & 50 & r9 & 26 & 0 & 5 \\
\hline
\end{tabular}

plurality of the voters in their states and casting their states' votes for the opposition party's candidate. In like fashion two delegations in states carried by Humphrey would have been under "cross-pressure"; and five state delegations in states carried by Wallace would have been similarly pressured. Five state votes would presumably have been nullified by an even split in the partisan make-up of the delegation.

If the election had been referred to a joint session of the two Houses, with each member having an individual vote, the "cross-pressure" factor would simply become more wide-spread and acute, as the following analysis shows:

TABLE 2

Senate Seats Compared with Presidential Election Results, ig68

\begin{tabular}{lcccc}
\hline \hline & $\begin{array}{c}\text { Rep. Senators } \\
\text { (Elected \& } \\
\text { Holdovers) }\end{array}$ & $\begin{array}{c}\text { Dem. Senators } \\
\text { (Elected) }\end{array}$ & $\begin{array}{c}\text { Dem. Senators } \\
\text { (Holdovers) }\end{array}$ & Total \\
\hline $\begin{array}{l}\text { State for } \\
\text { Nixon: }\end{array}$ & 33 & II & 20 & 64 \\
\hline & $\begin{array}{c}\text { Dem. Senators } \\
\text { (Elected \& } \\
\text { Holdovers) }\end{array}$ & $\begin{array}{c}\text { Rep. Senators } \\
\text { (Elected) }\end{array}$ & $\begin{array}{c}\text { Rep. Senators } \\
\text { (Holdovers) }\end{array}$ & \\
\hline $\begin{array}{l}\text { State for } \\
\text { Humphrey: }\end{array}$ & r6 & 3 & 7 & 26 \\
\hline & & $\begin{array}{c}\text { Dem. Senators } \\
\text { (Elected) }\end{array}$ & $\begin{array}{c}\text { Dem. Senators } \\
\text { (Holdovers) }\end{array}$ & \\
$\begin{array}{l}\text { State for } \\
\text { Wallace: }\end{array}$ & 0 & 4 & 6 & ro \\
\hline
\end{tabular}

So far as the Senate is concerned $5^{\mathrm{r}}$ newly-elected or holdover Senators would have been "out-of-line" in a partisan sense with the recently expressed popular results in their respective states. Of these, $3 \mathrm{I}$ would have been Democratic Senators in states carried by Nixon; ro would have been Republican Senators in states carried 
by Humphrey; and Io would have been Democratic Senators in states carried by Wallace.

The House picture would have been equally muddled on the matter of the popular vote in the district as compared with the partisan character of the representative chosen as shown by table 3 :

TABLE 3

House Seats Compared with Presidential Election Results, ig68

\begin{tabular}{lcccc}
\hline \hline & Rep. elected & Dem. elected & AIP elected & Total \\
\hline District for Nixon & $\mathrm{I} 60$ & 66 & 0 & 226 \\
District for Humphrey & 28 & 133 & 0 & $\mathrm{I6 \textrm {r }}$ \\
District for Wallace & 4 & 44 & 0 & 48 \\
\cline { 2 - 5 }$\quad$ Total & $\mathrm{I92}$ & 243 & 0 & 435 \\
\hline
\end{tabular}

A total of I42 House seats would have been held by partisans "out-of-line" with the presidential election results in their districts. Nixon carried 66 districts in which Democrats were elected; Humphrey 28 districts in which Republicans were elected; and 44 Democrats and 4 Republicans were elected in districts that voted for Wallace.

Thus on a joint voting basis in Congress a total of 193 members would have had to make the difficult choice between supporting their party's candidate or registering the revealed wishes of their constituencies for another party's candidate. Caught in this kind of "bind" would have been xro Democratic and 32 Republican House members, and 4I Democratic and Io Republican Senators. This amounts to approximately 44 per cent of the entire membership. How they would actually have resolved this dilemma one can only guess.

\section{$\mathrm{V}$}

\section{ConcLusion}

Viewed in its long range aspect, retention of language in a presidential election reform amendment reserving to Congress power to resolve in one way or another an inconclusive first step result in the election of the President might well prove to have most far-reaching consequences. Depending on the nature of the provisions for resolving the election on the basis of the first stage results, candidates for Congress might well become de facto presidential electoral candidates. The national party organization could be expected in that case, as they have done with the problem of the "disloyal" elector candidates on their party tickets, to exert pressure on the local party organization to put up under the party label only candidates for Congress whose loyalty to the national party leadership can be depended on. A "fencestraddling" congressional candidate on the matter of his choice for President would 
be opposed by a party "regular" whose loyalty is secure. Candidates for Congress would necessarily have to tie themselves more closely to the national party leadership, and rise or fall with the fortunes of the national party in their respective constituencies. The relationship of the President to his congressional party element would become closer, and party discipline in Congress would doubtless approach more closely to that found in a parliamentary democracy.

Use of some other method than referral to Congress of an inconclusive popular election for President, such as a run-off election device, on the other hand, would tend to keep the constituency bases of members of Congress and of the President more distinct and separate. While it might strengthen him in his role as head of government by giving him a political base different from that of the local and state party hierarchy, his party's members in Congress would by the same token remain in a stronger position to challenge his leadership, if so inclined. In fashioning a presidential election reform amendment, it would be well, therefore, for the members of Congress to recognize that the mechanics of the system they devise can have profound implications with respect to their relationship to their presidential candidate and the national party organizational leadership generally. It may further continuance of a viable system of checks and balances, or it may promote movement toward subordinating the congressional party of the President to a much greater degree of executive leadership than is now the case. 